\title{
Connexin 43 Hemichannels Are Permeable to ATP
}

\author{
Jian Kang, ${ }^{1}$ Ning Kang, ${ }^{1}$ Ditte Lovatt, ${ }^{2}$ Arnulfo Torres, ${ }^{2}$ Zhuo Zhao, ${ }^{1}$ Jane Lin, ${ }^{1}$ and Maiken Nedergaard ${ }^{2}$ \\ ${ }^{1}$ Department of Cell Biology and Anatomy, New York Medical College, Valhalla, New York 10595, ${ }^{2}$ Division of Glial Disease and Therapeutics, Center for \\ Translational Neuromedicine, Department of Neurosurgery, University of Rochester Medical Center, Rochester, New York 14642
}

\begin{abstract}
Astrocytes are electrically nonexcitable cells that communicate by means of $\mathrm{Ca}^{2+}$ signaling. Long-distance intercellular Ca ${ }^{2+}$ waves are initiated by release of ATP and activation of purinergic receptors on nearby cells. Previous studies have implicated connexin 43 (Cx43) in ATP release, but definitive proof that ATP exits through $\mathrm{Cx} 43$ hemichannels does not exist. Here, through several alternative approaches, we show that ATP anions can permeate through $\mathrm{Cx} 43$ hemichannels. First, openings of $\mathrm{Cx} 43$ hemichannels were detected in both cell-attached and inside-out patch recordings in C6 cells expressing Cx43, but not in C6 cells expressing Cx43-eGFP (enhanced green fluorescent protein) or a $\mathrm{C}$-terminus truncation mutant of $\mathrm{Cx} 43$. Second, $\mathrm{Cx} 43$ hemichannel openings were inhibited by three structurally different gap-junction channel blockers, but not by the $\mathrm{P} 2 \mathrm{X}_{7}$ blocker Brilliant blue G. Third, bioluminescence imaging of ATP combined with single-channel recording in the inside-out patch configuration showed that ATP efflux coincided with channel openings and was absent when the $\mathrm{Cx} 43$ hemichannel was closed. Fourth, ion replacement experiments confirmed that $\mathrm{Cx} 43$ hemichannels are permeable to ATP. In summary, these observations provide the first direct evidence for efflux of ATP through $\mathrm{Cx} 43$ hemichannels. Furthermore, a putative Cx43 hemichannel with characteristics identical to the $\mathrm{Cx} 43$ hemichannel in C6 cells was identified in the membrane of hippocampal astrocytes in acutely prepared slices.
\end{abstract}

Key words: gap junction; astrocyte; $\mathrm{Cx} 43$ hemichannel; bioluminescence; $\mathrm{P} 2 \mathrm{X}_{7}$; ATP

\section{Introduction}

Gap junctions are a subset of membrane channels that allow diffusion of ions and small molecules between the interiors of coupled cells. Gap junctions are composed of connexins (Kumar and Gilula, 1996; Theis et al., 2005). Six connexins oligomerize to form a hemichannel (connexon), which docks with a hemichannel in a neighboring cell to form a gap-junction channel. It was long believed that opening of hemichannels and efflux of cellular metabolites below $\sim 1 \mathrm{kDa}$ would rapidly lead to cell death. Evidence provided over the last several years has shown that hemichannels do exhibit short-lasting openings resulting in controlled release of cytosolic compounds. One important intracellular metabolite is ATP, which is present in millimolar concentration in the cytosol and sufficiently small to permeate at least some hemichannels (Bennett et al., 2003). Once ATP is released, it acts as a potent transmitter triggering rises in $\mathrm{Ca}^{2+}$ in neighboring cells by activation of $\mathrm{P} 2 \mathrm{Y}$ receptors, resulting in longdistance increases in $\mathrm{Ca}^{2+}$ (Goodenough and Paul, 2003). Because ATP-mediated $\mathrm{Ca}^{2+}$ signaling represents the primary

\footnotetext{
Received Nov. 13, 2007; revised March 15, 2008; accepted March 17, 2008.

This work was supported in part by National Institutes of Health, National Institute of Neurological Disorders Stroke Grants NS38073 and NS50315, New York State Spinal Cord Injury Research Board Grant C020925, and US Army Medical Research and Material Command Grant 07254001. We thank Michael V. L. Bennett and Camillo Peracchia for suggestions and comments on this manuscript.

Correspondence should be addressed to either of the following: Jian Kang, Department of Cell Biology and Anatomy, New York Medical College, 30 SunshineCottage Road, Valhalla, NY 10595, E-mail:Jian_Kang@NYMC.edu; or Maiken Nedergaard, Division of Glial Disease and Therapeutics, Center for Translational Neuromedicine, Department of Neurosurgery, University of Rochester Medical Center, 601 Elmwood Avenue, Rochester, NY 14642, E-mail: Nedergaard@URMC.Rochester.edu.

D0I:10.1523/JNEUROSC1.5048-07.2008

Copyright $\odot 2008$ Society for Neuroscience $\quad 0270-6474 / 08 / 284702-10 \$ 15.00 / 0$
}

intercellular signaling pathway among electrically nonexcitable cells including astrocytes, considerable efforts have focused on determining the mechanism of ATP release (Cotrina et al., 1998). The primary evidence for efflux of ATP through hemichannels has been that exogenous expression of either connexin 26 (Cx26), $\mathrm{Cx} 32$, or $\mathrm{Cx} 43$ by $\mathrm{Cx}$-deficient cell lines, including C6, N2A, and HeLa cells, leads to a marked increase in ATP release and uptake of fluorescent indicators ( $<1 \mathrm{kDa})$ (Cotrina et al., 1998). The notion that hemichannels can mediate ATP release has been supported (Arcuino et al., 2002; Stout et al., 2002; Saez et al., 2003; Gomes et al., 2005; Zhao et al., 2005) and extended to efflux of other transmitters, including glutamate (Ye et al., 2003). Nevertheless, the evidence linking ATP efflux to hemichannels is indirect. The lack of direct proof that ATP can exit through Cx43 hemichannels is a concern because a number of studies have shown that $\mathrm{Cx} 43$ regulates the expression of other genes (Naus et al., 2000; Iacobas et al., 2004). Moreover, alternative ATP release pathways do exist, including volume-sensitive channels (Sabirov et al., 2001) and P2X receptor-gated channels (Anderson et al., 2004; Suadicani et al., 2006), as well as exocytosis of vesicular ATP (Coco et al., 2003; Pangrsic et al., 2007; Zhang et al., 2007). Thus, the possibility exists that $\mathrm{Cx} 43$ expression modulates other release pathways and that exogenous expression of $\mathrm{Cx} 43$ indirectly enhances ATP release.

We have here tested whether ATP anions can permeate hemichannels using two alternative and highly sensitive assays. We combined single-channel recordings with luminescence imaging of ATP and demonstrated that opening of Cx43 hemichannels is linked to efflux of ATP. Also, single-channel recordings provided direct evidence that flux of ATP carries current through Cx43 hemichannels. Furthermore, recordings from hippocampal 
slices showed that astrocytes in situ exhibit channel openings with characteristics similar to those of $\mathrm{Cx} 43$ hemichannels in transfected cells. Our study provides critical direct evidence for ATP release through $\mathrm{Cx} 43$ hemichannels.

\section{Materials and Methods}

Slice preparation. Brain slices were prepared as described previously (Kang et al., 1998). Briefly, postnatal day 8 (P8)-P12 Sprague Dawley rats were anesthetized with pentobarbitone sodium $(55 \mathrm{mg} / \mathrm{kg})$ and decapitated. Brains were removed rapidly and glued with the posterior surfaces down. Transverse brain slices of $300 \mu \mathrm{m}$ were cut with a vibratome (TPI, St. Louis, MO) in a cutting solution containing (in mM) $2.5 \mathrm{KCl}, 1.25$ $\mathrm{NaH}_{2} \mathrm{PO}_{4}, 10 \mathrm{MgSO}_{4} 0.5 \mathrm{CaCl}_{2}, 10$ glucose, $26 \mathrm{NaHCO}_{3}$, and 230 sucrose. Slices containing the hippocampus were incubated in the slice solution gassed with $5 \% \mathrm{CO}_{2}$ and $95 \% \mathrm{O}_{2}$ for $1-7 \mathrm{~h}$ and then transferred to a recording chamber that was perfused with the slice solution gassed with $5 \% \mathrm{CO}_{2}$ and $95 \% \mathrm{O}_{2}$ at room temperature $\left(23-24^{\circ} \mathrm{C}\right)$ for recording. The standard slice solution contained (in $\mathrm{mm}$ ) $126 \mathrm{NaCl}, 2.5 \mathrm{KCl}, 1.25$ $\mathrm{NaH}_{2} \mathrm{PO}_{4}, 2 \mathrm{MgCl}_{2}, 2 \mathrm{CaCl}_{2}, 10$ glucose, and $26 \mathrm{NaHCO}_{3}, \mathrm{pH} 7.4$ when gassed with $95 \% \mathrm{O}_{2}$ and $5 \% \mathrm{CO}_{2}$.

Transfection of Cx43 in C6 cells. Truncation mutant M257 was a gift from Mario Delmar (State University of New York Upstate Medical University, Syracuse, NY). Deletion of 125 aa from the C terminal was achieved by replacing serine codon 257, TCA, with a stop codon, TGA (Dunham et al., 1992; Homma et al., 1998). Cx43-eGFP, Cx43 fused at its $\mathrm{C}$ terminus with enhanced green fluorescent protein (eGFP), was obtained from James Weiss (Cardiovascular Research Laboratory, University of California, Los Angeles, Los Angeles, CA) (John et al., 1999). C6 cells stably expressing Cx43, Cx43-eGFP, GFP, or M257, all under the cytomegalovirus (CMV) promoter (C6-Cx43 ${ }^{+}$, C6-Cx43-eGFP, C6GFP, or C6-M257, respectively), or deficient of Cx43 (C6-Cx43- cells, transfected with empty vector under the $\mathrm{CMV}$ promoter) were generated as described previously (Lin et al., 1998; John et al., 1999). The identities of these stable transfectants were verified by immunocytochemistry. M257 lacks the majority of $\mathrm{C}$ terminal and is detected with rabbit antiCx43 antibody (Zymed, South San Francisco, CA) whose target includes the area immediate after the last transmembrane domain that is retained in the truncated mutant. The expression of Cx43-eGFP is easily detected by the green fluorescence, but is also confirmed with antibodies against Cx43 (Zymed clones 3D8A5, CX-1B1, and polyclonal) as well as against GFP (Invitrogen, Eugene, OR).

Patch-clamp recordings. Cx43-expressing C6 cells or slices were placed in a small chamber that had a volume of $2 \mathrm{ml}$ and were superfused with standard slice solution gassed with $5 \% \mathrm{CO}_{2}-95 \% \mathrm{O}_{2}$ at room temperature $\left(23-24^{\circ} \mathrm{C}\right)$. Cells were visualized with a $\times 63$ water-immersion objective and differential inference contrast (DIC) optics (BX51 upright microscope; Olympus Optical, New York, NY). Patch electrodes with a resistance of 4-7 M $\Omega$ were pulled from KG-33 glass capillaries (inner diameter, $1.0 \mathrm{~mm}$; outer diameter, $1.5 \mathrm{~mm}$; Garner Glass, Claremont, CA) using a P-97 electrode puller (Sutter Instruments, Novato, CA). Cell-attached patch and inside-out patch recordings (Hamill et al., 1981) were performed using an Axopatch 200B amplifier (Molecular Devices, Sunnyvale, CA). For inside-out patch configuration, cell-attached patch recording was first performed to examine channel activity, and then inside-out patch configuration was obtained by excising pipettes from patched cells. For ion replacement experiments, a multitube delivery system that allowed rapid solution changes (Kang et al., 1996) was used. Patches with seal resistance $<5 \mathrm{G} \Omega$ were rejected. Signals were sampled every $50 \mu$ s with pClamp Clampex 9.0 and filtered through an eight-pole Bessel low-pass filter with a $1 \mathrm{kHz}$ cutoff frequency.

Bioluminescence imaging of ATP passing through a single channel. An inside-out patch was excised from Cx43-expressing C6 cells and was placed at the mouth of a glass pipette that contained luciferace and luciferine (K salt, 1:3). A slight pressure was applied to the enzyme pipette to keep blowing the enzyme solution out. A hypothermal CCD camera (VersArray 1300B; Princeton Instruments, Monmouth Junction, NJ) was used to detect changes in light intensity that were caused by ATP binding to the enzyme. A membrane depolarization of $+80 \mathrm{mV}$ (intra- cellular) was applied, and channel openings and light changes were simultaneously monitored in inside-out patch recording and ATPbinding light imaging.

Data analysis. pClamp Clampfit 9.0 was used to analyze channel activities. A 50\% threshold criterion was used to determine the duration of open and closed events. Logarithmic distributions of the open and closed duration were exponentially fitted using maximal likelihood method. The binwidth was determined automatically with Clampfit. Amplitude histograms were analyzed via pClampfit and unitary currents for unitary conductance calculation were obtained from amplitude histograms. The current across the membrane carried by an ion is given by the GoldmanHodgkin-Katz (GHK) equation:

$$
I_{\mathrm{S}}=P_{\mathrm{S}} z_{\mathrm{S}}^{2} \frac{V_{\mathrm{m}} F^{2}}{R T} \frac{[S]_{i}-[S]_{0} e^{-Z_{\mathrm{S}} V_{\mathrm{m}} F / R T}}{1-e^{-Z_{\mathrm{S}} V_{\mathrm{m}} F / R T}},
$$

where $I_{\mathrm{S}}$ is the current across the membrane carried by ion $\mathrm{S}$, measured in amperes, $P_{\mathrm{S}}$ is the permeability of ion $\mathrm{S}, z_{\mathrm{S}}$ is the charge of ion $\mathrm{S}, V_{\mathrm{m}}$ is the transmembrane potential in volts, $F$ is the Faraday constant, $R$ is the gas constant, $T$ is the absolute temperature, measured in kelvins, $[S]_{\mathrm{i}}$ is the intracellular concentration of ion $\mathrm{S}$, and $[\mathrm{S}]_{\mathrm{o}}$ is the extracellular concentration of ion S. $P_{\mathrm{ATP}} / P_{\mathrm{Na}}$ was calculated by the derived GHK equation with $V_{\mathrm{Rev}}\left(V_{\mathrm{m}}\right),\left[\mathrm{Na}^{+}\right]_{\mathrm{o}}=2\left[\mathrm{ATP}^{2-}\right]_{\mathrm{o}}$, and $\left[\mathrm{Na}^{+}\right]_{\mathrm{i}}=\left[\mathrm{ATP}^{2-}\right]_{\mathrm{i}}=0 \mathrm{M}$ :

$$
P_{\mathrm{ATP}} / P_{\mathrm{Na}}=\frac{1}{2} \frac{1-e^{-2 V_{\mathrm{Rev} F} F T}}{e^{V_{\mathrm{Rev} F / R T}}-1} .
$$

$P_{\mathrm{Na}} / P_{\mathrm{Cl}}$ and $P_{\mathrm{K}} / P_{\mathrm{Cl}}$ were calculated by the derived GHK equation:

$$
P_{\mathrm{Na} \text { or K }} / P_{\mathrm{CI}}=e^{V_{\mathrm{Rev} F / R T}} \text {. }
$$

Statistic data are presented as mean \pm SE if not indicated.

\section{Results}

\section{Characteristics of $\mathrm{Cx} 43$-dependent channels}

To examine whether there are ATP-permeable Cx43 hemichannels in the cell membrane, we first performed cell-attached patch recordings in $\mathrm{Cx} 43$-expressing C6 cells. The pipette solution contained $130 \mathrm{~mm} \mathrm{NaCl}, \mathrm{Na}_{2} \mathrm{ATP}$, or MgATP. To block the opening of $\mathrm{K}^{+}$channels that are expressed in these cells, an unselective $\mathrm{K}^{+}$ channel blocker, tetraethylammonium (TEA; $20 \mathrm{~mm}$ ), was added to the pipette solution. To activate $\mathrm{Cx} 43$-dependent channels, a voltage step of $-160 \mathrm{mV}\left(V_{\mathrm{p}}\right)$ was applied to the cell-attached patch pipette, so that an intracellular potential of $+80 \mathrm{mV}$ was obtained if the resting membrane potential (RMP) was $-80 \mathrm{mV}$. At the end of experiments, the actual RMP for each cell was recorded immediately after the cell-attached patches were transformed to the whole-cell configuration. The mean RMP of Cx43-C6 cells was $-72.3 \pm 1.3 \mathrm{mV}(n=30$ cells $)$. Values of membrane potential and $I-V$ relationships are shown with this correction. An upward current indicated an outward current across the patch membrane. A Cx43 hemichannel with a low opening probability $\left(P_{\mathrm{o}}, 0.006 \pm 0.003, n=20\right.$ patches $)$ was observed in $38 \%$ (30 of 80 ) of cell-attached patches with $\mathrm{Na}_{2}$ ATP (Fig. $1 A$, top trace, o). The $P_{\mathrm{o}}$ for each patch was justified by the channel number that was determined after inside-out patch recording. Cx43 hemichannels in a cell-attached patch with 130 $\mathrm{mM} \mathrm{Na}_{2} \mathrm{ATP}$ showed openings with a mean amplitude of $15.5 \pm$ $0.3 \mathrm{pA}\left(V_{\mathrm{p}}=-160 \mathrm{mV}, n=21\right.$ patches). Similar Cx43dependent channel openings were observed in $40 \%$ (6 of 15) of cell-attached patches with $\mathrm{NaCl}$. To examine the $I-V$ relationships and reversal potentials $\left(V_{\mathrm{Rev}}\right)$ for $\mathrm{Cx} 43$-dependent channels, we used either voltage holding steps $\left(V_{\mathrm{p}},-160-0 \mathrm{mV}\right.$; step, $20 \mathrm{mV}$ ) or a ramp command $\left(V_{\mathrm{p}}\right)$ from -160 to $0 \mathrm{mV}$ (duration, $1000 \mathrm{~ms}$ ). Channel openings reversed at the membrane potential of $5.4 \pm 1.2 \mathrm{mV}$ (Fig. $1 \mathrm{~B}$, closed circle) ( $n=6$ patches). The slope conductance of fast-gating openings was calculated with the $I-V$ 

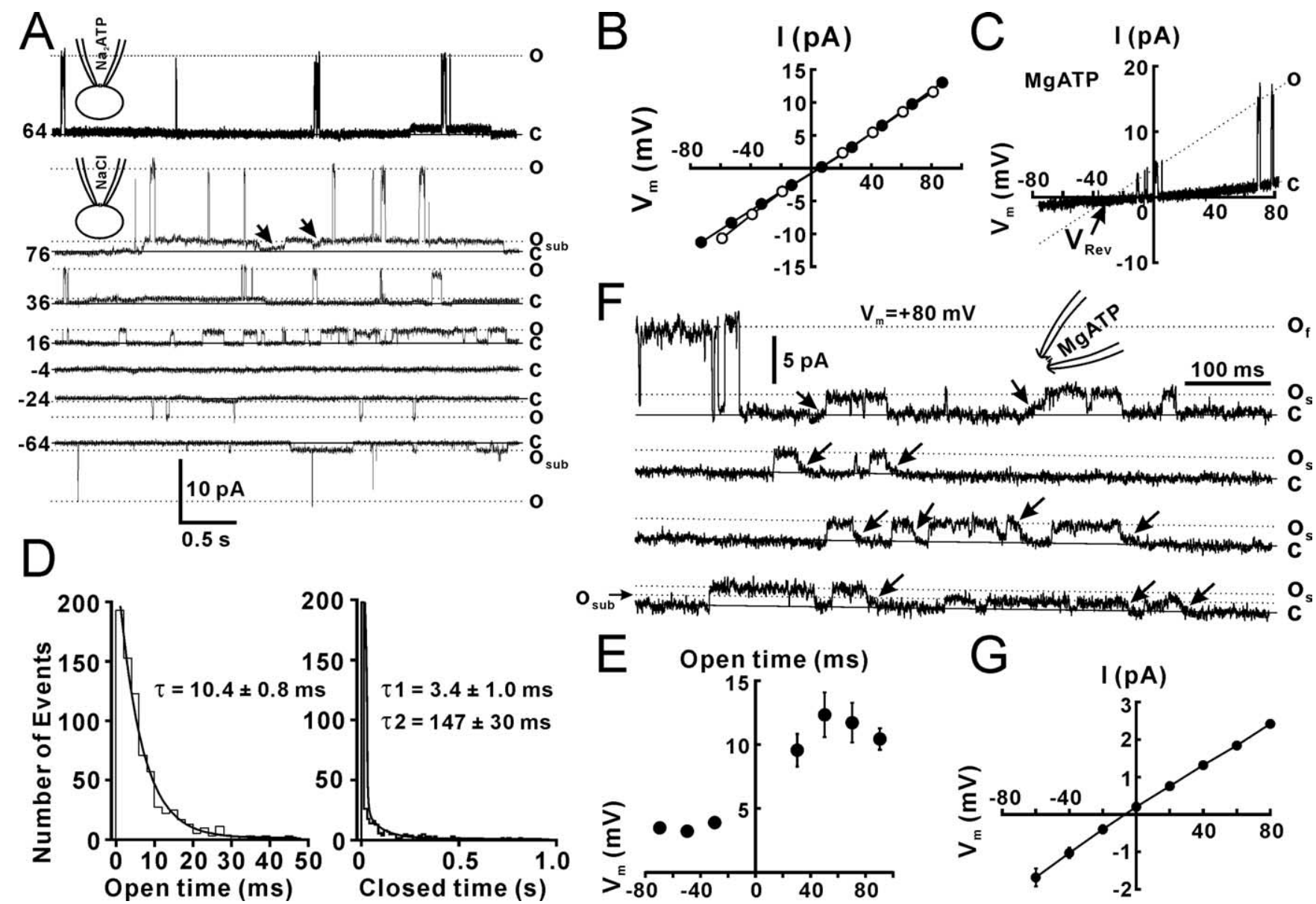

Figure 1. Cx43 hemichannels in cell-attached patches from Cx43-expressing C 6 cells. A, Cell-attached patch recording with the pipette solution containing $130 \mathrm{~mm} N \mathrm{Na}_{2} \mathrm{ATP}$ (top trace) or NaCl (bottom traces) and $20 \mathrm{~mm}$ TEA showed the opening (0) and closing (c) states of $\mathrm{C} \times 43$ hemichannels. Voltage steps of $-160 \mathrm{to} 0 \mathrm{mV}$ were applied to the patch pipette. $V_{\mathrm{m}}$ that was the difference between a voltage step and the RMP was presented at the left of each trace. A substate of long openings with slow transitions was also observed ( $0_{\text {sub }}$ and arrows). $\boldsymbol{B}$, The $I-V$ relationship for cell-attached recordings with $\mathrm{NaCl}$ (open circle, $n=5$ patches) or $\mathrm{Na}_{2} A T P$ (closed circle, $n=6$ patches). C, The $I-V$ current of $(x 43$ hemichannels with MgATP (MgATP) in the patch pipette. D, 0 pen and closed time distributions for a $\mathrm{C} \times 43$ hemichannel with a $\mathrm{Na}_{2} \mathrm{ATP}$ pipette at holding potential of $70 \mathrm{mV}$. The decay constant $(\tau)$ for open and closed time was calculated by exponential regression with one and two constants, respectively. The numbers indicate the mean decay constants $(\tau)$. $\boldsymbol{E}$, The mean open time constant at different holding potentials. The open time of $(x 43$ hemichannels is rectified. $n=6$ channels. $F$, Inside-out patch recording from a representative inside-out patch showed fast-gating openings $\left(0_{f}\right)$ and slow-gating openings $\left(0_{s}\right)$. A subconductance of slow-gating openings $\left(0_{\text {sub }}\right)$ was also observed. The inside-out patch was excised from the cell-attached patch configuration into the artificial CSF solution. $V_{\mathrm{m}}$ across patches was $+80 \mathrm{mV}$. G, The $I-V$ relationship for inside-out recordings with voltage steps. Error bars indicate SEM.

curve (Fig. $1 B$, closed circle). Cx43-dependent channels with the fast kinetics recorded with $\mathrm{Na}_{2} \mathrm{ATP}$ pipettes had a conductance of $165 \pm 3 \mathrm{pS}$ ( $n=6$ patches). Cx43-dependent channels with $\mathrm{NaCl}$ in the pipette showed a slope conductance of $167 \pm 6 \mathrm{pS}(n=6$ patches). A long opening substate of $\mathrm{Cx} 43$-dependent channels was also observed and the slope conductance with $\mathrm{Na}_{2} \mathrm{ATP}$ and $\mathrm{NaCl}$ was $15 \pm 3 \mathrm{pS}$ ( $n=6$ patches) and $17 \pm 2 \mathrm{pS}$, respectively. Recordings with different voltage steps showed that more fastgating openings occurred at positive potentials (Fig. $1 A$ ), which resulted from increased open time at positive potentials. The channel open time with $\mathrm{Na}_{2} \mathrm{ATP}$ pipettes was measured by fitting the open time distribution with a single exponential (Fig. 1D, open time). The closed time distribution required two exponentials for a reasonable fit with decay constants (Fig. $1 D$, closed time). The open time at different holding potentials showed that channel openings at the positive range of potentials all had a longer open time than at negative voltages (Fig. $1 E$ ), suggesting that opening of $165 \mathrm{pS} \mathrm{Cx} 43$ hemichannels is rectified with longer open time outwardly, but has no remarked rectification in the amplitude. When MgATP replaced $\mathrm{Na}_{2} \mathrm{ATP}$ in the pipette, channel openings were also observed, but with a smaller amplitude $\left(11.1 \pm 0.7 \mathrm{pA} ; n=18\right.$ patches; $\left.V_{\mathrm{p}}=-160 \mathrm{mV}\right)$. The $I-V$ current showed that the $V_{\mathrm{Rev}}$ shifted to the negative direction (Fig. $1 C$, $V_{\text {Rev }}$ ), suggesting that the channel permeability to $\mathrm{Mg}^{2+}$ is lower than $\mathrm{Na}^{+}$. The conductance of $\mathrm{Cx} 43$-dependent channels with MgATP pipettes was $115 \pm 4 \mathrm{pS}$ ( $n=16$ patches).

To further characterize Cx43-dependent channels, we obtained the inside-out patch configuration after cell-attached patch recording. Inside-out patches from cell-attached patches were excised into the artificial CSF that contained $2 \mathrm{mM} \mathrm{Ca}^{2+}$. Eighty-five percent of patches (11 of 13 patches) that showed openings of $\mathrm{Cx} 43$-dependent channels while attached also exhibited channel openings when excised. Only $26 \%$ of patches ( 6 of 23 patches) that showed no openings of $\mathrm{Cx} 43$-dependent channels while attached exhibited channel openings when excised. Fastgating openings occurred only for several seconds (Fig. $1 \mathrm{~F}, \mathrm{o}_{\mathrm{f}}$ ), and then openings became restricted to slow transitions of $26 \pm$ $0.4 \mathrm{pS}\left(n=20\right.$ patches) (Fig. $1 \mathrm{~F}$, arrows and $\mathrm{o}_{\mathrm{s}}$ ). In some patches, a subconductance state of $14 \pm 0.6 \mathrm{pS}$ ( $n=10$ patches) with slowgating transitions (Fig. $1 F, \mathrm{o}_{\text {sub }}$ ), perhaps corresponding to the outward substate in cell-attached patches. Analysis of channel kinetics showed that the $26 \mathrm{pS}$ state had much longer open times 


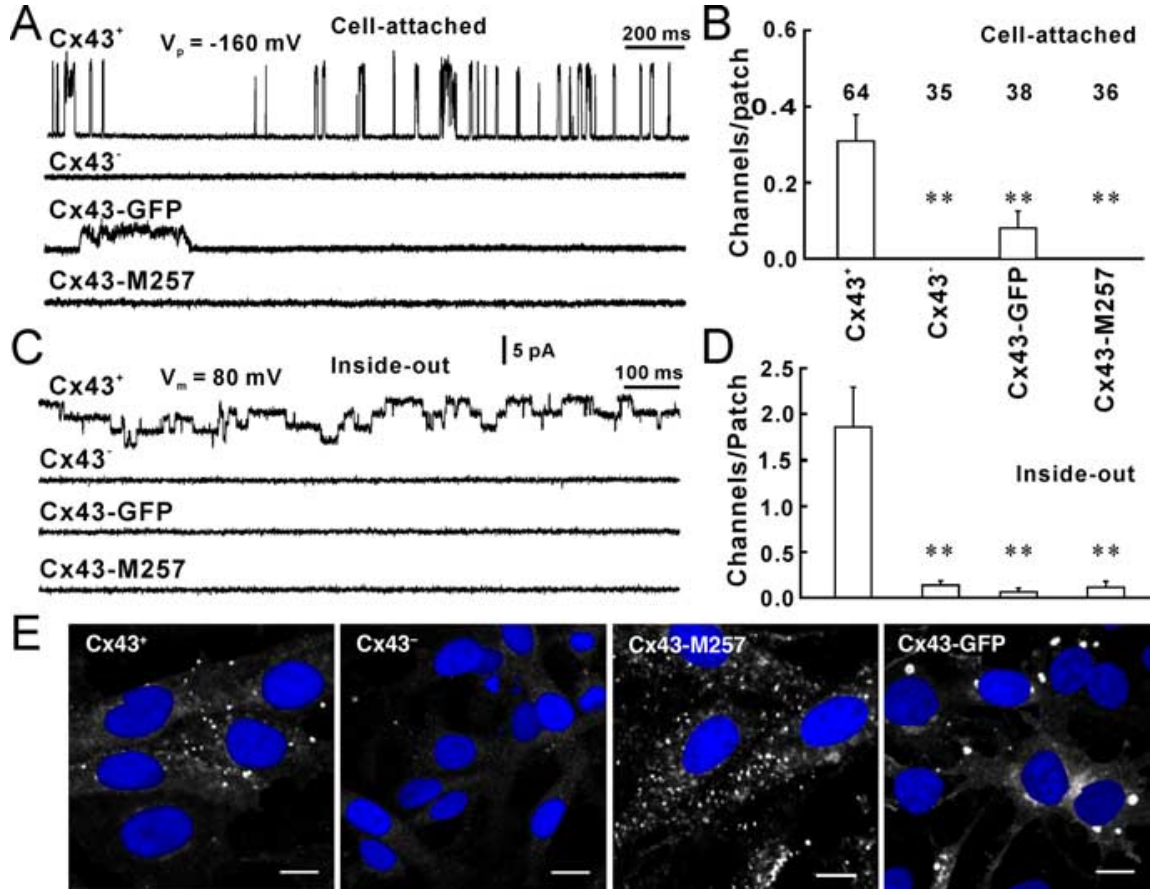

Figure 2. The recorded channel is a $(x 43$ hemichannel. $\boldsymbol{A}$, Fast-gating openings of $\mathrm{C} \times 43$ hemichannels in cell-attached patches from a Cx43-expressing C6 cell $\left(\mathrm{C}_{4} 43^{+}\right)$, a control Cx43-deficient cell (Cx43-) that does not express $\mathrm{Cx} 43$, a $\mathrm{Cx} 43$-eGFPexpressing C6 cell (Cx43-GFP), and a truncated Cx43-expressing C6 cell (Cx43-M257). B, The number of Cx43 hemichannels per cell-attached patch. $C$, Twenty-six picosiemen openings of $\mathrm{Cx} 43$ hemichannels in inside-out patches from $\mathrm{Cx} 43^{+}, \mathrm{Cx}_{43}{ }^{-}$, Cx43-eGFP, and Cx43-M257 cells. D, The mean number of $26 \mathrm{pS}$ Cx43 hemichannels per inside-out patch. ${ }^{* *} p<0.01$ compared with $\mathrm{C}_{4} 43^{+}$, Student's $t$ test. $\boldsymbol{E}$, Immunolabeling against $\mathrm{C} \times 43$ (white) in $\mathrm{C} \times 43^{+}, \mathrm{C} \times 43^{-}$, and $\mathrm{C} \times 43-\mathrm{M} 257 \mathrm{C} 6$ cells and immunolabeling against eGFP in CX43-eGFP C6 cells (CX43-GFP). Scale bars, $10 \mu \mathrm{m}$. Error bars indicate SEM.

(31 $\pm 14 \mathrm{~ms}, n=27$ patches) and higher open probability $\left(P_{\mathrm{o}}\right.$, $0.7 \pm 0.03)$ than the fast-gating state in cell-attached patches $\left(P_{\mathrm{o}}\right.$, $0.006 \pm 0.003 ; p<0.01$, Student's $t$ test $)$. The substate opening in inside-out patches had a conductance ( $26 \mathrm{pS}$ ) similar to that of the substate of cell-cell channels (26 pS) (Wang et al., 2006). Twenty-six picosiemen openings reversed at the membrane potential near $0 \mathrm{mV}$ (Fig. $1 G$ ).

\section{The recorded channel is a $\mathrm{Cx} 43$ hemichannel}

To further demonstrate that the recorded channels were $\mathrm{Cx} 43$ hemichannels, we first performed single-channel recordings from control Cx43-deficient cells, which do not form gap junctions and lack $\mathrm{Cx} 43$, and found no channel openings in cellattached patches (Fig. 2A, B, Cx43-) and very few $26 \mathrm{pS}$ openings in inside-out patches (Fig. 2C,D, $\mathrm{Cx} 43^{-}$). These results suggest that the recorded channel is a $\mathrm{Cx} 43$ hemichannel. Second, we used C6 cells expressing Cx43-GFP. The eGFP tag has been reported previously to specifically block fast gating between the substate and fully open state of $\mathrm{Cx} 43$, leaving only slow transitions (5-50 ms) between fully open and closed states, both in hemichannels and cell-cell channels (Contreras et al., 2003). Cell-attached patch recording from C6-Cx43-eGFP cells showed few channel openings ( 3 of 38 patches) that were of reduced amplitude, but larger than the substate (Fig. 2A, B, Cx43-eGFP). Inside-out patches from Cx43-eGFP cells showed a significantly decrease in channel openings (Fig. 2C,D, Cx43-eGFP). Third, we expressed a truncation of Cx43 (M257) with amino acids deleted from the $\mathrm{COOH}$ terminus in $\mathrm{C} 6$ cells. This mutation also blocks 165 pS openings in cell-attached patches (Fig. 2A, B, Cx43-M257) and $26 \mathrm{pS}$ openings in inside-out patches (Fig. 2C,D, Cx43M257). Immunolabeling against $\mathrm{Cx} 43$ (Fig. 2E, white) indicated that the expression level of $\mathrm{Cx} 43$ (Fig. $2 \mathrm{E}$, $\mathrm{Cx}_{4} 3^{+}$) and $\mathrm{Cx} 43-\mathrm{M} 257$ (Fig. 2 E, Cx43M257) were comparable, whereas C6 cells transfected with an empty vector exhibited very low level of $\mathrm{Cx} 43$ expression (Fig. $2 E$, $\mathrm{Cx} 43^{-}$). Similar immunolabeling against Cx43-eGFP indicated that the fusion protein was densely expressed and localized in plaques (Fig. 2 E, Cx43-GFP, white). These results suggest that hemichannel activity requires more of the $\mathrm{C}$ terminus than left after truncation of $\mathrm{Cx} 43$ in the $\mathrm{Cx} 43$ M257-expressing cells and add additional evidence to the concept that the channel recorded in C6 cells expressing Cx43 indeed is the $\mathrm{Cx} 43$ hemichannel. Finally, we used the gap-junction channel inhibitors, gadolinium $\left(\mathrm{Gd}^{3+}, 25 \mu \mathrm{M}\right)$, carbenoxolone $(100 \mu \mathrm{M})$, and the anion channel inhibitor 5-nitro-2-(3-phenylpropylamino)benzoic acid (NPPB; $100 \mu \mathrm{M})$ to block 26 pS channels in inside-out patches. Blockers had been applied in the bath solution by perfusion before inside-out patches were excised from cells, so that blockers had rapid access to the channels. $\mathrm{Gd}^{3+}$, carbenoxolone, and NPPB all blocked channel openings in inside-out patches (Fig. $3 A, B$ ). The mean $P_{\mathrm{o}}$ for each channel was reduced from $\sim 0.6$ to $\sim 0.1$. The results further confirm that the recorded channel is a Cx43 hemichannel. Interestingly, NPPB first shortened the open times of $\mathrm{Cx} 43$ hemichannels (Fig. 3A, NPPB, $6 \mathrm{~s}$ ) before fully blocking openings (Fig. 3A, NPPB, $24 \mathrm{~s}$ ). The $\mathrm{P} 2 \mathrm{X}_{7}$ receptor/channel complex has been reported to mediate ATP release (Suadicani et al., 2006). To exclude the $\mathrm{P} 2 \mathrm{X}_{7}$ channel, we added the $\mathrm{P} 2 \mathrm{X}_{7}$ receptor blocker, Brilliant blue $\mathrm{G}$ ( 1 $\mu \mathrm{M})$, to the patch pipette solution. In the presence of Brilliant blue $\mathrm{G}$ and $130 \mathrm{~mm} \mathrm{Na} \mathrm{N}_{2} \mathrm{ATP}$ in the pipettes, cell-attached patch recordings still showed $165 \mathrm{pS}$ openings of $\mathrm{Cx} 43$ hemichannels (Fig. 3C,D, cell-attached, BBG), and inside-out patch recordings showed 26 pS Cx43 hemichannel activity (Fig. 3C,D, inside-out, $\mathrm{BBG})$. When the pipette solution containing $130 \mathrm{mM} \mathrm{NaCl}$ without ATP, which is a P2Y agonist, 27\% (3 of 11) of cell-attached patches still showed $167 \mathrm{pS}$ hemichannel activity (Fig. 3D, cellattached, $\mathrm{NaCl}$ ) and $73 \%$ (8 of 11) of inside-out patches showed $\mathrm{Cx} 43$ hemichannel activities (Fig. 3D, inside-out, $\mathrm{NaCl}$ ). When the pipette solution containing $130 \mathrm{~mm} \mathrm{NaCl}$ and BBG $(1 \mu \mathrm{M})$ without ATP, 33\% (4 of 12) of cell-attached patches (Fig. 3D, cell-attached, $\mathrm{NaCl} / \mathrm{BBG}$ ) and $75 \%$ (9 of 12) of inside-out patches (Fig. 3D, inside-out, $\mathrm{NaCl} / \mathrm{BBG}$ ) showed hemichannel activities. These results suggest that the channel recorded in this study is not a $\mathrm{P} 2 \mathrm{X}_{7}$ channel.

\section{Bioluminescence detection of ATP coincide with opening of} Cx43 hemichannels

To test whether the Cx43 hemichannel is permeable to $\mathrm{ATP}^{2-}$, we used a liquid-nitrogen-cooled CCD camera to detect photons generated by the luciferin/luciferase reaction when ATP passed through open $26 \mathrm{pS} \mathrm{Cx} 43$ hemichannels in inside-out patches (Fig. 4A, DIC, p2). Inside-out patches were obtained with a patch pipette (Fig. 4A, DIC, p1) containing $130 \mathrm{~mm} \mathrm{Na}_{2} \mathrm{ATP}$. To avoid a high background of light emission caused by the passive leakage 


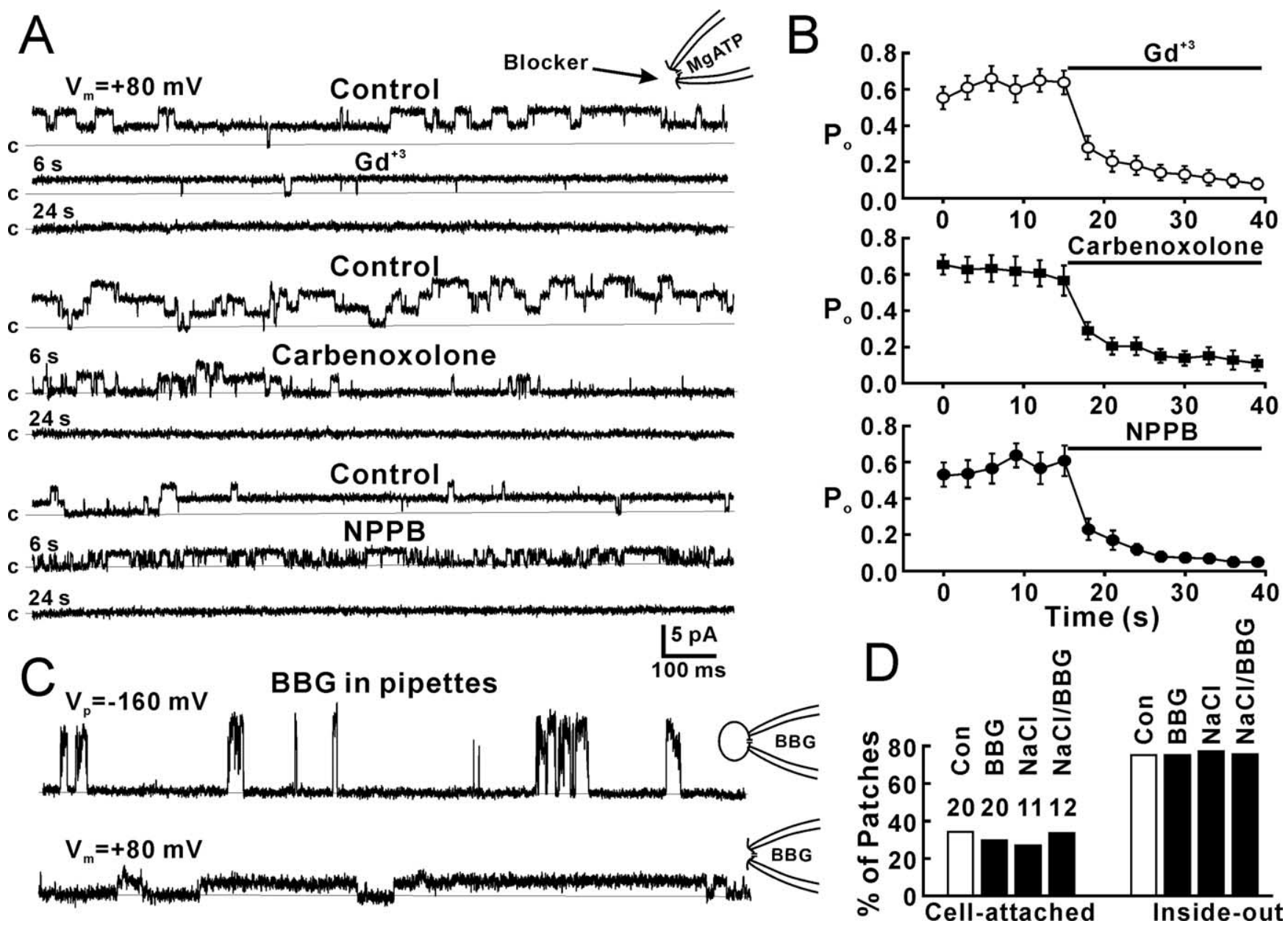

Figure 3. Blockade of $\mathrm{C} x 43$ hemichannels by gap-junction and anion channel blockers. $A$, Inside-out patch recording of $26 \mathrm{pS} C \times 43$ hemichannels during control, $6 \mathrm{~s}$, and $24 \mathrm{~s}$ after application of gadolinium $\left(\mathrm{Gd}^{+3}, 25 \mu \mathrm{M}\right)$, carbenoxolone $(100 \mu \mathrm{M})$, and NPPB $(100 \mu \mathrm{M})$. $\boldsymbol{B}$, Mean data showing the time course of the $P_{0}$ of $26 \mathrm{pS}\left(x 43\right.$ hemichannels during control and application of $\mathrm{Gd}{ }^{+3}$, carbenoxolone, and NPPB. $P_{0}$ was calculated for each channel during 2 s using the Clampfit program of $p$ Clamp 9.0. $p<0.001$, one-way ANOVA; $n=11,12$, and 9 patches for Gd ${ }^{+3}$, carbenoxolone, and NPPB, respectively. C, Cell-attached patch recording (top trace) and inside-out patch recording (bottom trace) in the presence of Brilliant blue $G(B B G, 1 \mu \mathrm{M})$ in the patch pipette. $\boldsymbol{D}$, Percentage of cell-attached and inside-out patches that showed 165 pS fast-gating openings (cell-attached patches) or $26 \mathrm{pS}$ substate openings (inside-out patches). Data from recordings with pipettes containing $\mathrm{Na}_{2} \mathrm{ATP}$ ( $\mathrm{Con}$ ), Brilliant blue $\mathrm{G}$ and $\mathrm{Na}_{2} \mathrm{ATP}$ (BBG), $\mathrm{NaCl}$ ( $\mathrm{NaCl}$ ), or Brilliant blue $\mathrm{G}$ and $\mathrm{NaCl}$ ( $\mathrm{NaCl} / \mathrm{BBG}$ ) were presented. Error bars indicate SEM.

of ATP from the cell from which the patch was excised, the patch pipette containing the inside-out patch was moved at least 200 $\mu \mathrm{m}$ under DIC microscopy. A second pipette (p2) containing the luciferin/luciferase mixture was placed at a distance of $\sim 10 \mu \mathrm{m}$ from the pipette containing the inside-out patch (Fig. $4 A$, DIC). A low pressure was applied to the enzyme pipette to provide a continuous stream of the luciferin/luciferase mixture. We used this arrangement to capture photon emission generated by ATP that escaped the patch pipette through the inside-out membrane patch (Fig. $4 A$, bottom left diagram). Inside-out patch recording was performed simultaneously with bioluminescence imaging to monitor channel openings and seal resistance. Patches with seals $<5 \mathrm{G} \Omega$ were rejected. Baseline images (Fig. $4 A$, baseline) were obtained before the inside-out patch pipette was moved to the mouth of the enzyme pipette. Patches without channel openings were used as controls (Fig. $4 B$ ). Figure $4 A$ shows a representative experiment, in which at least two $\mathrm{Cx} 43$ hemichannels were active simultaneously (Fig. $4 A$, traces at the top of each picture); openings were accompanied by increased light emission around the patch pipette. The emission was limited to the patch pipette side (Fig. 4A, $10 \mathrm{~s}-100 \mathrm{~s}$ ) because of flow from the pipette delivering the enzyme mixture (Fig. $4 A, \mathrm{p} 2$ ). When openings of $\mathrm{Cx} 43$ hemichannels declined, photon production also dimmed (Fig. $4 A$, after $60 \mathrm{~s}$ ). Figure $4 C$ showed that the channel $P_{\text {o }}$ (Fig. $4 C$, filled squares) declined with time, and the light intensity (Fig. $4 C$, filled circles) decreased after the decreased open probability. For patches without channel activity (Fig. 4C, open circles), no changes in the light intensity were observed. These results suggest that $\mathrm{Cx} 43$ hemichannels are permeable to ATP. To further test whether light intensity reflected influx of ATP, we first held inside-out patches at $-80 \mathrm{mV}$ that reversed channel unitary currents to be inward (Fig. $5 A, V_{\mathrm{h}}=-80 \mathrm{mV}$, traces). At holding potential of $-80 \mathrm{mV}$, an increase in light intensity was not observed despite multiple inward unitary currents channel openings (Fig. $5 A$, pictures, $C$, filled circles, $V_{\mathrm{h}}=-80 \mathrm{mV}$ ). Likely, the negative holding potential prevented influx at $\mathrm{ATP}^{2-}$. Changing the holding potential from -80 to $+80 \mathrm{mV}$ induced outward unitary currents (Fig. $5 A, V_{\mathrm{h}}=+80 \mathrm{mV}$, traces) and a marked increase in the light intensity (Fig. $5 A$, pictures, $C$, filled circles, $V_{\mathrm{h}}$ $=+80 \mathrm{mV}$ ), suggesting that the increase in the light intensity was caused by $\mathrm{ATP}^{2-}$ influx through the recorded hemichannel. To further demonstrate $\mathrm{ATP}^{2-}$ influx through hemichannels, we applied gap-junction channel inhibitors, $\mathrm{Gd}^{3+}(30 \mu \mathrm{M})$, carbenoxolone $(100 \mu \mathrm{M})$, and NPPB $(100 \mu \mathrm{M})$, into the bath solution to 

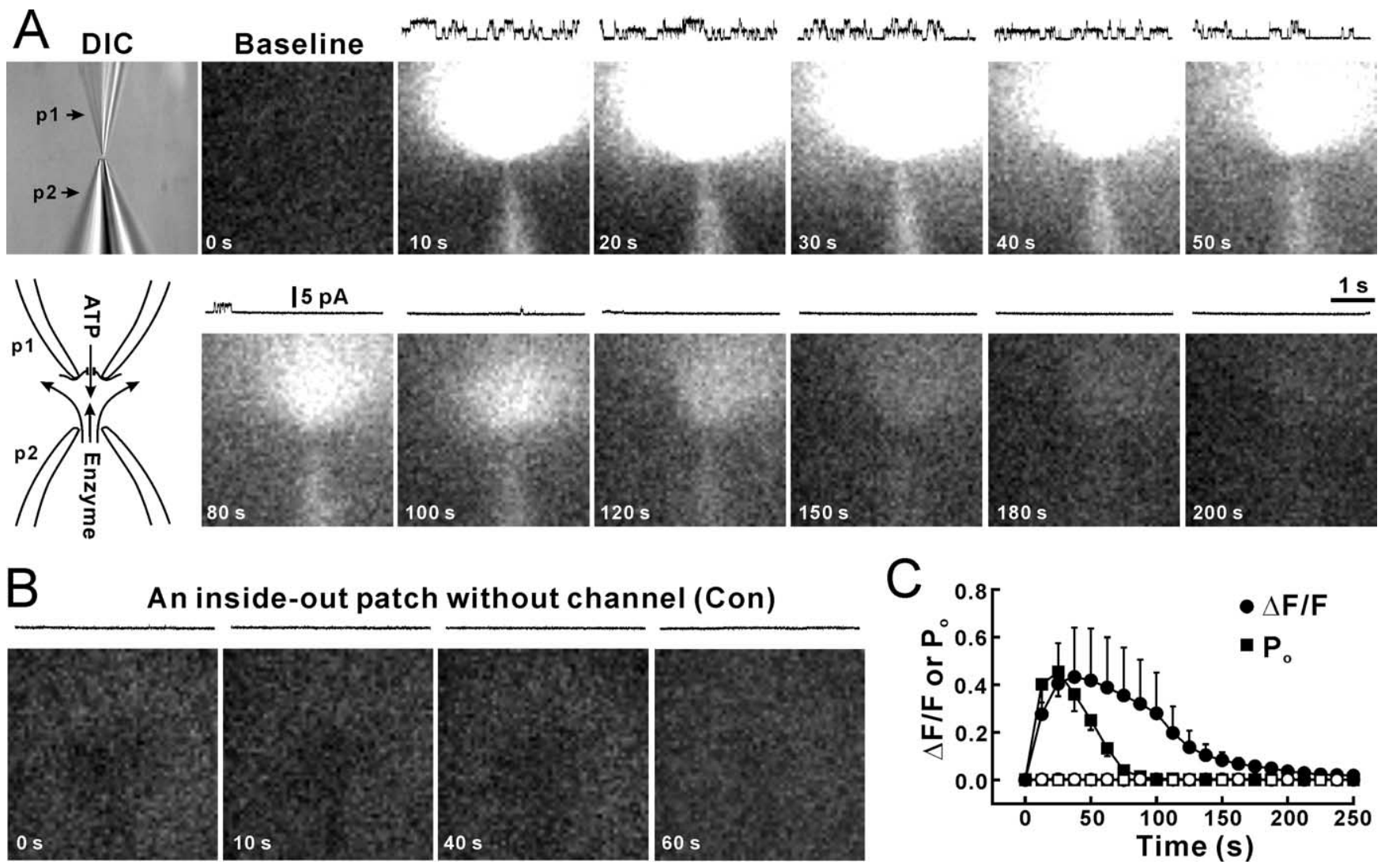

Figure 4. Detection of ATP influx through a single Cx43 hemichannel by luciferace/luciferine. $A$, An inside-out patch (DIC, p1) was excised from Cx43-expressing C6 cells. The pipette solution contained $130 \mathrm{~mm} \mathrm{Na}_{2}$ ATP. A baseline image was first obtained before the patch electrode was moved close to the puff pipette (DIC, p2) containing luciferase and luciferin (K salt, 1:3). A low pressure was applied to the puff pipette to eject the enzyme solution. When a voltage step of $+80 \mathrm{mV}$ (intracellular) was applied to the patch, channel openings were observed under voltage-clamp of the inside-out patch (traces over the images). Simultaneous imaging showed that light intensity increased with the channel activity. Channel openings declined after a few minutes for unknown reasons. $\boldsymbol{B}, A$ control inside-out patch without channel activity showed no light increase. $C$, The relationship between the increase in light intensity $(\Delta F / F$, filled circles; $F$ is the baseline) and the channel open probability $\left(P_{0}\right.$, filled squares) with patches containing channels. No light was emitted when the patch contained no active channels (open circles). The termination of channel activity preceded the termination of light increase, which reflects that flow of the solution takes time to remove released ATP. $n=6$ and 11 patches for the channel and no channel groups, respectively. Error bars indicate SEM.

block Cx43 hemichannels (Fig. $3 A, B$ ). Only patches that showed hemichannel activity during cell-attached patch recording or inside-out patch recording before application of blockers (Fig. $5 B$, control) were used in this experiment. In the presence of gap-junction inhibitors, neither the hemichannel activity or the increase in light intensity were detected (Fig. 5B,C, open squares), confirming a key role of hemichannels in ATP influx.

To further analyze the ATP permeability of $\mathrm{Cx} 43$ hemichannels, we measured the $V_{\text {Rev }}$ of $26 \mathrm{pS}$ openings in inside-out patches with intracellular sucrose that does not have any charges. The $V_{\mathrm{Rev}}$ was measured by static holding steps. To correct changes in junction potential caused by sucrose replacement, the baseline at $0 \mathrm{mV}$ was adjusted to $0 \mathrm{pA}$ before recording at each step. When inside-out patches containing $130 \mathrm{mM} \mathrm{Na}_{2} \mathrm{ATP}$ faced to the sucrose solution $(280 \mathrm{mM})$, unitary outward currents were still observed at positive potentials (Fig. $6 \mathrm{~A}, 0-40 \mathrm{mV}$ ). Because only $\mathrm{Na}^{+}$and $\mathrm{ATP}^{2-}$ in patch pipettes were current carriers, outward currents should be ATP ${ }^{2-}$ currents. The $V_{\text {Rev }}$ was $-15 \pm 6 \mathrm{mV}$ (Fig. $6 D$, inside-out, NaATP/Sucr). The ratio of $P_{\mathrm{Na}}$ to $P_{\mathrm{ATP}}\left(P_{\mathrm{Na}} / P_{\mathrm{ATP}}\right)$ was calculated by the derived GoldmanHodgkin-Katz Equation 2, and the $P_{\mathrm{Na}} / P_{\mathrm{ATP}}$ ratio is 1:2.5. When patch pipettes contained $130 \mathrm{~mm} \mathrm{NaCl}$ and faced to the sucrose solution, the $V_{\text {Rev }}$ was $-18 \pm 6 \mathrm{mV}$ (Fig. $6 D$, inside-out, $\mathrm{NaCl} /$ Sucr) and the $P_{\mathrm{Na}} / P_{\mathrm{Cl}}$ ratio is $1: 2$, suggesting that $P_{\mathrm{Cl}}$ is larger than $P_{\mathrm{Na}}$, but little smaller than $P_{\mathrm{ATP}}$. When patch pipettes contained
$130 \mathrm{mM} \mathrm{KCl}$ and faced to the sucrose solution, the $V_{\mathrm{Rev}}$ was $-25 \pm 4 \mathrm{mV}$ (Fig. $6 D$, inside-out, $\mathrm{KCl} / \mathrm{Sucr}$ ) and the $P_{\mathrm{K}} / P_{\mathrm{Cl}}$ ratio is 1:2.7. $P_{\mathrm{Na}} / P_{\mathrm{K}}=1: 0.7$ was obtained by the $P_{\mathrm{Na}} / P_{\mathrm{Cl}}$ and $P_{\mathrm{K}} / P_{\mathrm{Cl}}$ ratios. As a control, $130 \mathrm{~mm} \mathrm{NaCl}$ was placed in both sides of inside-out patches, the $V_{\operatorname{Rev}}$ was close to $0 \mathrm{mV}$ (Fig. $6 D$, insideout, $\mathrm{NaCl} / \mathrm{NaCl})(-0.2 \pm 0.3 \mathrm{mV})$.

To demonstrate the ATP permeability of 165 pS Cx43 hemichannels in cell-attached patches, we measured the $V_{\mathrm{Rev}}$ of 165 pS Cx43 hemichannels with dual patch-clamp recordings (Kang et al., 2000) in single Cx43-expressing C6 cells. We used one pipette with $\mathrm{Na}_{2} \mathrm{ATP}$ for cell-attached patch recording (Fig. $6 \mathrm{~B}$, left pipette) and another pipette with the sucrose solution $(280 \mathrm{~mm})$ for whole-cell recording (Fig. $6 \mathrm{~B}$, right pipette) to replace intracellular contents. 165 pS openings of $\mathrm{Cx} 43$ hemichannels were still observed $50 \mathrm{~min}$ after forming the wholecell configuration with the sucrose pipette (Fig. $6 B$, NaATP/ Sucr). Cell-attached patch recordings with sucrose on both extracellular and intracellular sides did not show any channel openings (Fig. 6B, Sucr/Sucr), indicating that the cytoplasmic content was replaced by sucrose. Single-cell-attached patch recording with pipettes containing pure sucrose showed channel openings that reversed at a potential near $E_{\mathrm{K}}$ (Fig. $6 A-C$, Sucr/Cyto) $(-84.3 \pm$ $2.2 \mathrm{mV}$ ), suggesting that the $\mathrm{Cx} 43$ hemichannel is permeable to $\mathrm{K}^{+}$and patch pipettes with sucrose are able to detect channel activity. Openings of 165 pS Cx43 hemichannels with NaATP/ 


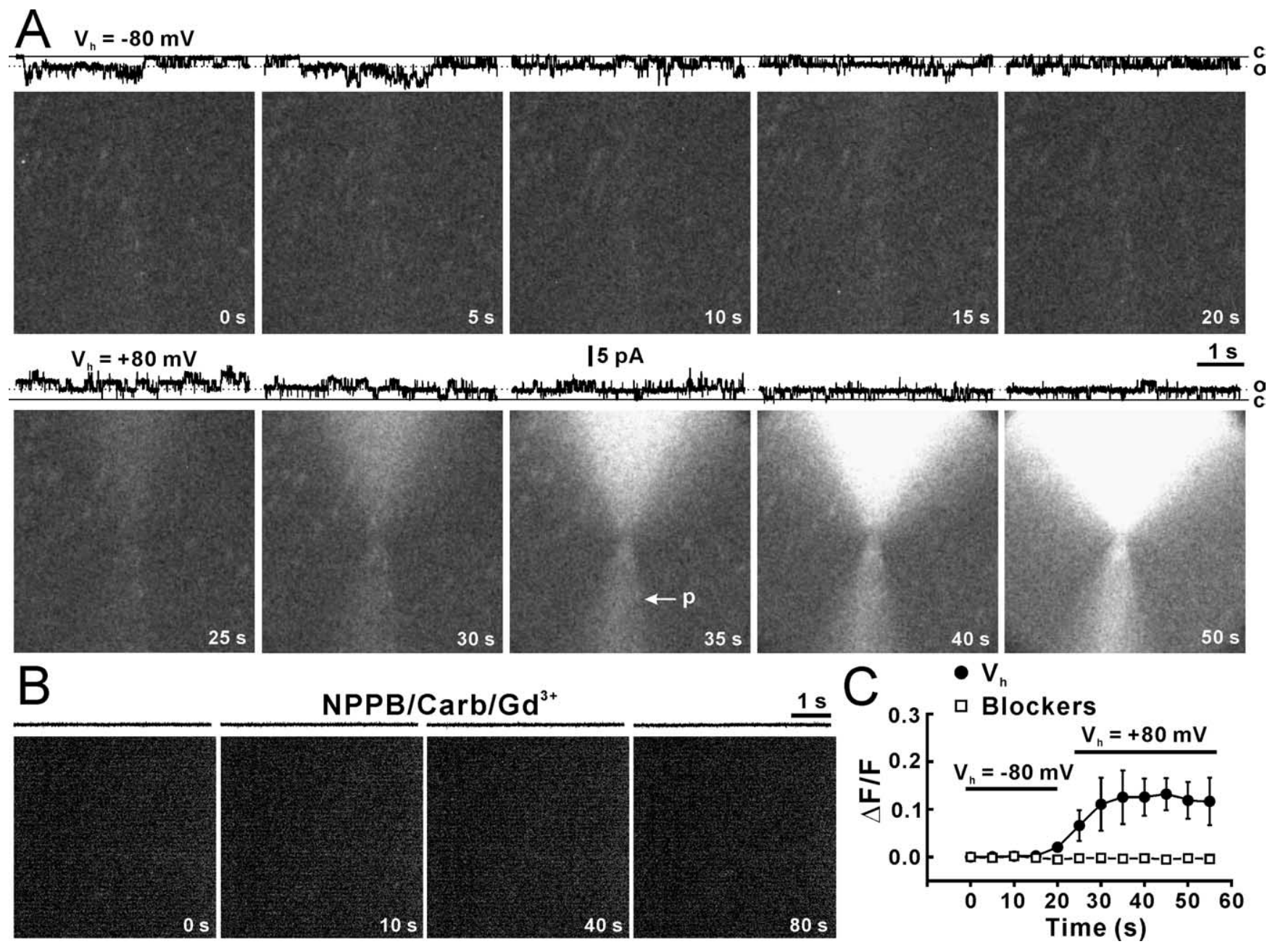

Figure 5. Blockade of ATP influx by negative holding or hemichannel blockers. $A$, Light induced by ATP influx when an inside-out patch was held at $-80 \mathrm{mV}\left(V_{\mathrm{h}}=-80 \mathrm{mV}\right)$ and $+80 \mathrm{mV}\left(V_{\mathrm{h}}\right.$ $=+80 \mathrm{mV}$ ). Recording traces at the top of each panel illustrate hemichannel activities at open $(0)$ and closed $(c)$ states. The arrow $(\mathrm{p})$ indicates the pipette containing the enzyme that delivered by a light, but sustained pressure. B, ATP influx when gap-junction blockers, $\mathrm{Gd}^{3+}(30 \mu \mathrm{M})$, carbenoxolone (Carb, $\left.100 \mu \mathrm{M}\right)$, and NPPB (100 mM) were applied in the bath solution. Patches showing hemichannel activity before action of blockers (control) were chosen to move to the enzyme pipette. The inside-out patch was held at $+80 \mathrm{mV}$. C, Relative light intensity $(\Delta F / F)$ against time during holding at $-80 \mathrm{mV}$ (filled circles, $V_{\mathrm{h}}=-80 \mathrm{mV}$ ) and $+80 \mathrm{mV}$ (filled circles, $V_{\mathrm{h}}=+80 \mathrm{mV} ; n=7$ patches) or in the presence of gap-junction blockers (open squares; $n=9$ patches; two-way ANOVA, $p<0.01$ compared with absence of blockers). Error bars indicate SEM.

sucrose reversed at $-7 \pm 1.8 \mathrm{mV}$ (Fig. $6 B, C, \mathrm{NaATP} / \mathrm{Sucr}$ ). The ratio of $P_{\mathrm{Na}}$ to $P_{\mathrm{ATP}}\left(P_{\mathrm{Na}} / P_{\mathrm{ATP}}\right)$ calculated by the derived Goldman-Hodgkin-Katz Equation 2 is 1:1.5. The results suggest that both $165 \mathrm{pS}$ and $26 \mathrm{pS} \mathrm{Cx} 43$ hemichannels are more permeable to $\mathrm{ATP}^{2-}$ than $\mathrm{Na}^{+}$.

Putative Cx43 hemichannels in astrocytes in

hippocampal slices

To test whether $\mathrm{Cx} 43$ hemichannel open in astrocytes in vivo, we performed cell-attached patch and inside-out patch recordings from CA1 astrocytes in hippocampal slices acutely prepared from P8-P12 rats. The patch pipette solution contained $130 \mathrm{mM}$ $\mathrm{Na}_{2} \mathrm{ATP}$ or MgATP and $20 \mathrm{~mm}$ TEA-Cl. Astrocytes were identified by DIC microscopy similarly as described by our previous study (Kang et al., 1998). Figure 7 shows 165 pS channel openings in a representative cell-attached patch (Fig. 7A) and $26 \mathrm{pS}$ openings in an inside-out patch (Fig. 7C) excised from an astrocyte in a slice. We only observed 165 pS channel openings in four cellattached patches and $26 \mathrm{pS}$ openings in 14 inside-out patches from a total of 700 astrocytes, suggesting that activity of the $\mathrm{Cx} 43$ hemichannel was low in slice astrocytes under physiological con- ditions. The $I-V$ relationship of the cell-attached patches showed that $165 \mathrm{pS}$ openings were voltage dependent and that $V_{\mathrm{Rev}}$ for the putative Cx43 hemichannels was close to zero (Fig. $7 B, D$, $V_{\text {Rev }}$ ), similar to the Cx43 hemichannels in Cx43-transfected C6 cells. Thus, although rare, a putative $\mathrm{Cx} 43$ hemichannel does exist in astrocytes in slices.

\section{Discussion}

This study provides the first direct evidence that ATP can pass through Cx43 hemichannels. Three alternative approaches were used to evaluate the permeability of ATP through Cx43 hemichannels. First, we used inside-out patches with a pipette solution containing $130 \mathrm{~mm} \mathrm{Na} \mathrm{NTP}_{2} \mathrm{AT}$, whereas the intracellular side of the patch was exposed to a pure sucrose solution. Under these conditions, frequent $26 \mathrm{pS}$ channel openings were detected as outward currents in patches obtained from C6-Cx43 ${ }^{+}$cells (Fig. 6A). The outward current is generated by efflux of ATP anions, because passage of $\mathrm{Na}^{+}$will result in an inward current. The $V_{\text {Rev }}$ were $-15 \mathrm{mV}$ in these experiments, suggesting that the permeability of $\mathrm{ATP}^{2-}$ is higher than $\mathrm{Na}^{+}\left(P_{\mathrm{Na}} / P_{\mathrm{ATP}}=1: 2.5\right)$, because $\mathrm{Na}^{+}$concentration was double of $\mathrm{ATP}^{2-}$ concentration 



B
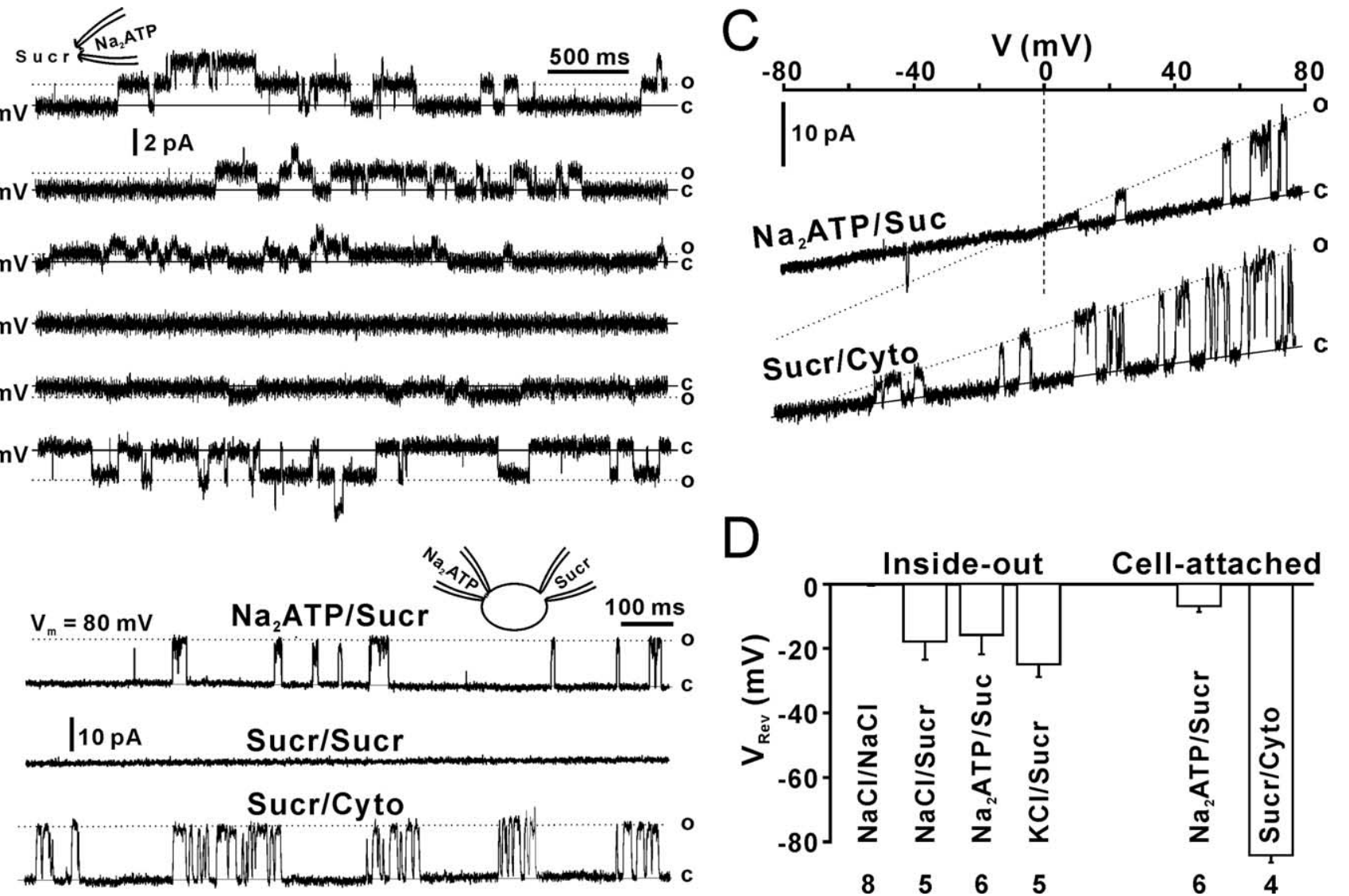

D

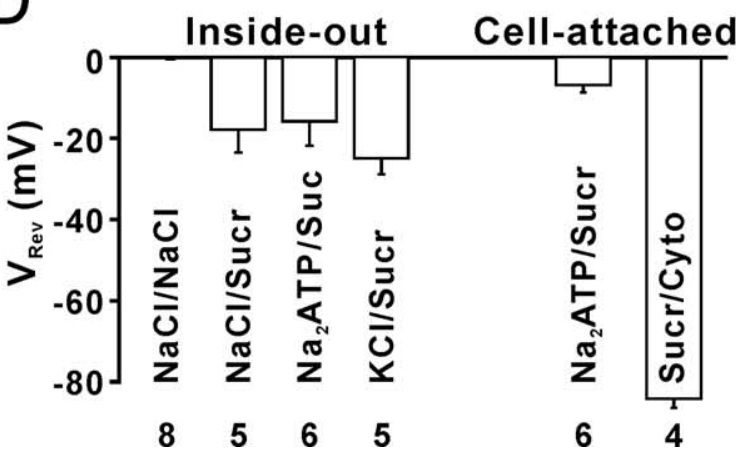

Figure 6. Permeability of $\mathrm{C} x 43$ hemichannels. $A$, Twenty-six picosiemen openings in an inside-out patch at different holding potentials (left numbers). $\boldsymbol{B}$, Top trace, Cell-attached patch recording with the patch pipette solution containing $\mathrm{Na}_{2}$ ATP. The cell was whole-cell clamped with a pipette containing $280 \mathrm{~mm}$ sucrose (NaATP/Sucr). Middle trace, Both cell-attached and whole-cell pipettes contained sucrose (Sucr/Sucr). Bottom trace, Single-cell-attached patch recording with the pipette solution containing sucrose (Sucr/Cyto). C, I-V relationships with extracellular Na,ATP and intracellular sucrose (NaATP/Sucr) or extracellular sucrose and intracellular cytoplasm (Sucr/Cyto). D, Reversal potentials $\left(V_{\text {Rev }}\right)$ from cell-attached patch (cell-attached) and inside-out patch recordings (inside-out) with equivalent intracellular and extracellular $\mathrm{NaCl}$ ( $\mathrm{NaCl} / \mathrm{NaCl})$, intracellular sucrose and extracellular $\mathrm{Na}_{2} \mathrm{ATP}(\mathrm{NaATP} / \mathrm{Sucr})$, or extracellular $\mathrm{NaCl}$ (NaCl/Sucr), extracellular $\mathrm{KCl}$ (KCI/Sucr), and extracellular $\mathrm{Na}_{2}$ ATP with cytoplasm (NaATP/Cyto). Error bars indicate SEM.

and sucrose has no charge. Second, we used dual patch-clamp recordings of Cx43-expressing cells to control the ion composition at both side of the patch. A cell-attached patch was obtained with a pipette containing $\mathrm{Na}_{2} \mathrm{ATP}$, whereas the pipette used for whole-cell recording contained pure sucrose. Under these conditions, the $V_{\mathrm{Rev}}$ of the $165 \mathrm{pS}$ opening state of $\mathrm{Cx} 43$ hemichannels was $-7 \mathrm{mV}$, again suggesting that $P_{\mathrm{ATP}}$ is larger than $P_{\mathrm{Na}}\left(P_{\mathrm{Na}} /\right.$ $\left.P_{\text {ATP }}=1: 1.5\right)$. Therefore, we conclude that $\mathrm{Cx} 43$ hemichannels are more permeable to $\mathrm{ATP}^{2-}$ than to $\mathrm{Na}^{+}$. The difference between of the $P_{\mathrm{Na}} / P_{\mathrm{ATP}}$ ratio in inside-out (1:2.5) and cell-attached (1:1.5) patch recordings likely reflect different permeability of 26 and $165 \mathrm{pS}$ hemichannels openings, but differences in the conditions under which the recordings were obtained may also play a role. Third, as an alternative approach to ion permeability analysis, we combined bioluminescence imaging of ATP with single hemichannel openings. ATP efflux from inside-out membrane patches sealed by gigaohm resistance was visualized using a highly sensitive CCD camera. The bath solution contained a mixture of luciferase and luciferin, which in the presence of ATP and $\mathrm{O}_{2}$ generates photons in a 1:1 ratio. We found that channel opening coincided with influx of ATP detected as a surge of light surrounding the pipette. Both electrophysiological and imaging experiments provided clear evidence in favor of the idea that ATP can permeate through the Cx43 hemichannel in cultured cells transfected with $\mathrm{Cx} 43$. Furthermore, a putative $\mathrm{Cx} 43$ hemichannel was identified in cell-attached and inside-out patches har- vested from hippocampal astrocytes in slice preparation. The number of patches that showed putative hemichannel activities was low, with only 14 channels in a group of experiments that included 700 inside-out patches. This low number of putative hemichannels may result from either low density of channels in the plasma membrane of astrocytes in situ or a tighter control of hemichannels in astrocytes than in C6 cells overexpressing Cx43 under the $\mathrm{CMV}$ promoter.

The characteristics of $\mathrm{Cx} 43$ hemichannels observed here share several similarities to previous reports on $\mathrm{Cx} 43$ hemichannels. We found that $\mathrm{Cx} 43$ hemichannels exhibited both the fast-gating and slow-gating state, that the conductance of the fast-gating state was about twice of conductance of fast-gating state of whole gap-junction channels, that the reversal potential was close to zero, that channel openings were voltage dependent, and that the slow-gating state exhibited a long open time and a high open probability (Contreras et al., 2003). However, the property of Cx43 hemichannels from our single-channel recordings differs on several points from previous reports from whole-cell recordings. The $26 \mathrm{pS}$ slow-gating openings in inside-out patches was similar to the conductance of the slow-gating state of whole gapjunction channels (Valiunas et al., 1997). Thus, although the conductance of the fast-gating state of $\mathrm{Cx} 43$ hemichannels was approximately double that of whole gap-junction channels, the slow-gating state did not exhibit a similar increase in conductance of $\mathrm{Cx} 43$ hemichannels compared with gap-junction chan- 

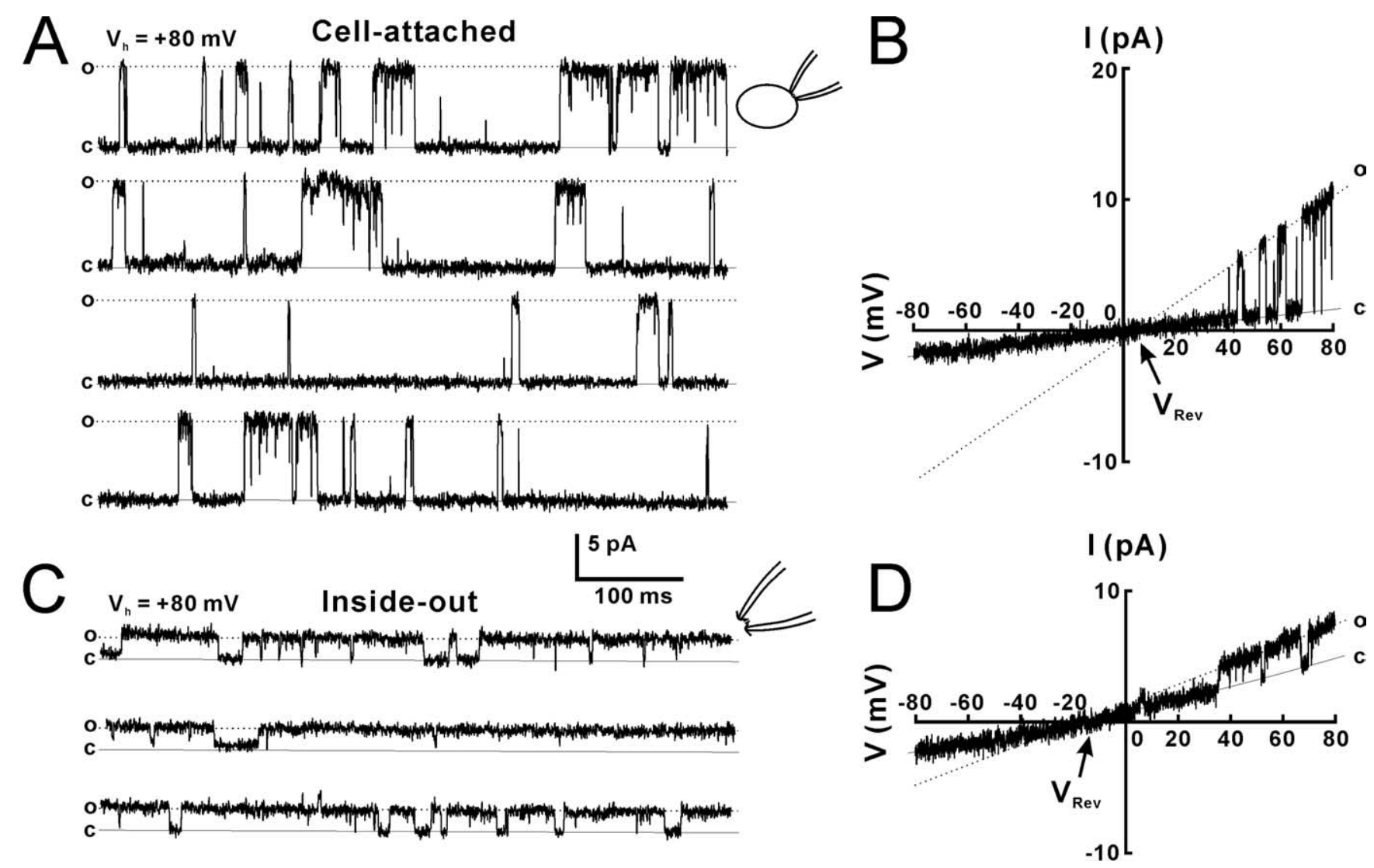

Figure 7. Putative $C x 43$ hemichannels in CA1 hippocampal astrocytes. $\boldsymbol{A}$, Putative $(x 43$ hemichannels in a cell-attached patch obtained from an astrocyte in an acute hippocampal slice. $\boldsymbol{B}$, The $I-V$ current for the channel in the cell-attached patch in $A$. C, Putative $(x 43$ hemichannels in an inside-out patch obtained from an astrocyte in a slice. $\boldsymbol{D}$, The $I-V$ current for the channel in the inside-out patch in $C$. The $V_{\text {Rev }}$ is close to zero, similar to that of $C x 43$ hemichannels from C $x 43$-expressing $C 6$ cells.

nels. We also identified a $15 \mathrm{pS}$ subconductance of the slowgating state in cell-attached patch recordings (Fig. $1 \mathrm{~A}, \mathrm{o}_{\text {sub }}$ ) and inside-out patches (Fig. $1 F, \mathrm{o}_{\text {sub }}$ ) that has not previously been reported. The $26 \mathrm{pS}$ slow-gating openings were the major open state of hemichannels, whereas the $15 \mathrm{pS}$ subconductance state was only occasionally observed in inside-out patches. On the contrary, $15 \mathrm{pS}$ subconductance was the major open state of the slow-gating openings in cell-attached patches. The preferential openings of the $15 \mathrm{pS}$ subconductance in intact cells compared with inside-out patches cannot easily be explained. However, hemichannel openings are likely regulated by a number of intracellular messengers or enzymes that are lost in the inside-out patch configuration.

Because expression of $\mathrm{Cx} 43$ is linked to changes in gene expression that could include expression of new channels, we collected additional data in both cell-attached and inside-out patches to support the notion that we were indeed recording openings of Cx43 hemichannels. These experiments showed that $\mathrm{Cx} 43$ hemichannel openings were low or undetectable in $\mathrm{Cx} 43$ deficient cells $\left(\mathrm{Cx}_{4} 3^{-}\right)$, and in cells expressing Cx43-eGFP or truncated $\mathrm{Cx} 43$. Both fast gating of $165 \mathrm{pS} \mathrm{Cx} 43$ hemichannels in cell-attached patches and slow gating of $26 \mathrm{pS} \mathrm{Cx} 43$ hemichannels in inside-out patches were almost absent in Cx43-eGFP cells, suggesting that $\mathrm{Cx} 43$-eGFP fusion protein blocked both fast- and slow-gating state, and reduced the amplitude of fast-gating $\mathrm{Cx} 43$ hemichannels in cell-attached patches (Fig. 2A,B, Cx43-eGFP). The significant reduction in the number of both fast- and slowgating $\mathrm{Cx} 43$ hemichannels detected in cells expressing truncated Cx43 (Cx43-M257 cells), suggests that Cx43 hemichannels with- out cytoplasmic $\mathrm{C}$ terminus are mostly closed, indicate that the $\mathrm{C}$ terminus play a regulatory role in $\mathrm{Cx} 43$ hemichannel opening. We also found that $\mathrm{Cx} 43$ hemichannels were blocked by three gap-junction channel blockers, and insensitive to $\mathrm{P} 2 \mathrm{X}_{7}$ receptor antagonist. Combined, these sets of experiments add supportive evidence to the notion that the channels identified in the previous recordings indeed was $\mathrm{Cx} 43$ hemichannels.

ATP release have in recent years been shown to play an important role in diverse processes in brain, including neurogenesis (Lin et al., 2007), long-term potentiation (Fellin et al., 2006), and secondary injury after ischemia (Melani et al., 2006), spinal cord injury (Wang et al., 2004), and experimental autoimmune encephalomyelitis (Witting et al., 2006) underpinning the importance of defining the pathways of ATP release. Although our study provide direct experimental evidence illustrating that ATP can permeate $\mathrm{Cx} 43$ hemichannels, the analysis does not exclude that other pathways can contribute to ATP release. Additional studies are needed to define the relative contribution of hemichannels versus vesicular release (Coco et al., 2003; Pangrsic et al., 2007; Zhang et al., 2007), P2X $\mathrm{X}_{7}$ receptor mediated ATP release (Suadicani et al., 2006), and volume-sensitive channels (Sabirov et al., 2001) during both physiological or pathophysiological conditions.

\section{References}

Anderson CM, Bergher JP, Swanson RA (2004) ATP-induced ATP release from astrocytes. J Neurochem 88:246-256.

Arcuino G, Lin JH, Takano T, Liu C, Jiang L, Gao Q, Kang J, Nedergaard M (2002) Intercellular calcium signaling mediated by point-source burst release of ATP. Proc Natl Acad Sci USA 99:9840-9845. 
Bennett MV, Contreras JE, Bukauskas FF, Saez JC (2003) New roles for astrocytes: gap junction hemichannels have something to communicate. Trends Neurosci 26:610-617.

Coco S, Calegari F, Pravettoni E, Pozzi D, Taverna E, Rosa P, Matteoli M, Verderio C (2003) Storage and release of ATP from astrocytes in culture. J Biol Chem 278:1354-1362.

Contreras JE, Saez JC, Bukauskas FF, Bennett MV (2003) Gating and regulation of connexin $43(\mathrm{Cx} 43)$ hemichannels. Proc Natl Acad Sci USA 100:11388-11393.

Cotrina ML, Lin JH, Alves-Rodrigues A, Liu S, Li J, Azmi-Ghadimi H, Kang J, Naus CC, Nedergaard M (1998) Connexins regulate calcium signaling by controlling ATP release. Proc Natl Acad Sci USA 95:15735-15740.

Dunham B, Liu S, Taffet S, Trabka-Janik E, Delmar M, Petryshyn R, Zheng S, Perzova R, Vallano ML (1992) Immunolocalization and expression of functional and nonfunctional cell-to-cell channels from wild-type and mutant rat heart connexin43 cDNA. Circ Res 70:1233-1243.

Fellin T, Pascual O, Haydon PG (2006) Astrocytes coordinate synaptic networks: balanced excitation and inhibition. Physiology (Bethesda) 21:208-215.

Gomes P, Srinivas SP, Van Driessche W, Vereecke J, Himpens B (2005) ATP release through connexin hemichannels in corneal endothelial cells. Invest Ophthalmol Vis Sci 46:1208-1218.

Goodenough DA, Paul DL (2003) Beyond the gap: functions of unpaired connexon channels. Nat Rev Mol Cell Biol 4:285-294.

Hamill OP, Marty A, Neher E, Sakmann B, Sigworth FJ (1981) Improved patch-clamp techniques for high-resolution current recording from cells and cell-free membrane patches. Pflugers Arch 391:85-100.

Homma N, Alvarado JL, Coombs W, Stergiopoulos K, Taffet SM, Lau AF, Delmar M (1998) A particle-receptor model for the insulin-induced closure of connexin43 channels. Circ Res 83:27-32.

Iacobas DA, Scemes E, Spray DC (2004) Gene expression alterations in connexin null mice extend beyond the gap junction. Neurochem Int 45:243-250.

John SA, Kondo R, Wang SY, Goldhaber JI, Weiss JN (1999) Connexin-43 hemichannels opened by metabolic inhibition. J Biol Chem 274:236-240.

Kang J, Huguenard JR, Prince DA (1996) Two types of BK channels in immature rat neocortical pyramidal neurons. J Neurophysiol 76:4194-4197.

Kang J, Jiang L, Goldman S, Nedergaard M (1998) Astrocyte-mediated potentiation of inhibitory synaptic transmission. Nat Neurosci 1:683-692.

Kang J, Huguenard JR, Prince DA (2000) Voltage-gated potassium channels activated during action potentials in layer $\mathrm{V}$ neocortical pyramidal neurons. J Neurophysiol 83:70-80.

Kumar NM, Gilula NB (1996) The gap junction communication channel. Cell 84:381-388.

Lin JH, Weigel H, Cotrina ML, Liu S, Bueno E, Hansen AJ, Hansen TW, Goldman S, Nedergaard M (1998) Gap-junction-mediated propagation and amplification of cell injury. Nat Neurosci 1:494-500.

Lin JH, Takano T, Arcuino G, Wang X, Hu F, Darzynkiewicz Z, Nunes M,
Goldman SA, Nedergaard M (2007) Purinergic signaling regulates neural progenitor cell expansion and neurogenesis. Dev Biol 302:356-366.

Melani A, Amadio S, Gianfriddo M, Vannucchi MG, Volonte C, Bernardi G, Pedata F, Sancesario G (2006) P2X7 receptor modulation on microglial cells and reduction of brain infarct caused by middle cerebral artery occlusion in rat. J Cereb Blood Flow Metab 26:974-982.

Naus CC, Bond SL, Bechberger JF, Rushlow W (2000) Identification of genes differentially expressed in C6 glioma cells transfected with connexin43. Brain Res Brain Res Rev 32:259-266.

Pangrsic T, Potokar M, Stenovec M, Kreft M, Fabbretti E, Nistri A, Pryazhnikov E, Khiroug L, Giniatullin R, Zorec R (2007) Exocytotic release of ATP from cultured astrocytes. J Biol Chem 282:28749-28758.

Sabirov RZ, Dutta AK, Okada Y (2001) Volume-dependent ATPconductive large conductance anion channel as a pathway for swellinginduced ATP release. J Gen Physiol 118:251-266.

Saez JC, Contreras JE, Bukauskas FF, Retamal MA, Bennett MV (2003) Gap junction hemichannels in astrocytes of the CNS. Acta Physiol Scand 179:9-22.

Stout CE, Costantin JL, Naus CC, Charles AC (2002) Intercellular calcium signaling in astrocytes via ATP release through connexin hemichannels. J Biol Chem 277:10482-10488.

Suadicani SO, Brosnan CF, Scemes E (2006) P2X7 receptors mediate ATP release and amplification of astrocytic intercellular $\mathrm{Ca}^{2+}$ signaling. J Neurosci 26:1378-1385.

Theis M, Sohl G, Eiberger J, Willecke K (2005) Emerging complexities in identity and function of glial connexins. Trends Neurosci 28:188-195.

Valiunas V, Bukauskas FF, Weingart R (1997) Conductances and selective permeability of connexin43 gap junction channels examined in neonatal rat heart cells. Circ Res 80:708-719.

Wang HZ, Brink PR, Christ GJ (2006) Gap junction channel activity in short-term cultured human detrusor myocyte cell pairs: gating and unitary conductances. Am J Physiol Cell Physiol 291:C1366-C1376.

Wang X, Arcuino G, Takano T, Lin J, Peng WG, Wan P, Li P, Xu Q, Liu QS, Goldman SA, Nedergaard M (2004) P2X7 receptor inhibition improves recovery after spinal cord injury. Nat Med 10:821-827.

Witting A, Chen L, Cudaback E, Straiker A, Walter L, Rickman B, Moller T, Brosnan C, Stella N (2006) Experimental autoimmune encephalomyelitis disrupts endocannabinoid-mediated neuroprotection. Proc Natl Acad Sci USA 103:6362-6367.

Ye ZC, Wyeth MS, Baltan-Tekkok S, Ransom BR (2003) Functional hemichannels in astrocytes: a novel mechanism of glutamate release. J Neurosci 23:3588-3596.

Zhang Z, Chen G, Zhou W, Song A, Xu T, Luo Q, Wang W, Gu XS, Duan S (2007) Regulated ATP release from astrocytes through lysosome exocytosis. Nat Cell Biol 9:945-953.

Zhao HB, Yu N, Fleming CR (2005) Gap junctional hemichannel-mediated ATP release and hearing controls in the inner ear. Proc Natl Acad Sci USA 102:18724-18729. 